\title{
COMMUNITY DEVELOPMENT IN SPORTS TOURISM DEVELOPMENT AS INCLUSIVE ECONOMIC DRIVER IN SOUTH SUMATERA
}

\author{
Zulkifli Harahap ${ }^{(1)}$, Titing Kartika ${ }^{(2)^{*}}$ \\ (1) Politeknik Pariwisata Palembang \\ (2) Sekolah Tinggi Ilmu Ekonomi Pariwisata YAPARI \\ zharahap.poltekpar@gmail.com, nengtiting_kartika@yahoo.co.id
}

Submitted: 30 September 2020 Revised: 5 October 2020

Accepted: 15 October 2020

\begin{abstract}
The development of the concept of Sports Tourism in Palembang in South Sumatra has been a government program; in this case, the Ministry of Tourism, Republic of Indonesia. The concept was developed to see the potential that exists among Jakabaring Sport City, an integrated Smart Sports Eco Green Complex. The presence of community empowerment in this concept's development includes three aspects: enabling, empowering, and protecting. Meanwhile, Sports Tourism drives the economy inclusive due to it has associated benefits that can be perceived by the public either directly or indirectly. Such benefits include transform and boost economic growth, income generation, poverty reduction, and expanding access and opportunity. The study used a qualitative descriptive approach that is to carry out observation, interviews, and documentation. The results of this study indicate that the development of Sport Tourism has a positive impact on the empowerment of local communities.
\end{abstract}

Keywords: Community Empowerment, Sport Tourism, Inclusive Economy, South Sumatera

\section{INTRODUCTION}

Tourism is now an essential part of Indonesia's national development, even considered as a leading sector. Indonesia has a diversity of tourism potential in several regions and provinces. At the implementation stage of tourism development should be based on locally owned making potential of the regions (Jamal \& Stronza, 2009). This ownership will strengthen the local brand that has a characteristic and a different character to other regions. Palembang, South Sumatra, besides, has the potential for nature-based tourism, culture, history, and cuisine. Another potential that can be developed is a sportsbased tourism development (Sports Tourism). Sports tourism has been developed in the region of Jakabaring Sport City. With their range of sporting activities, both national and international sports events in Palembang and equipped with facilities. Palembang will be the Center of Excellence (COE) Sport Tourism in Indonesia in the future (Revindo, et.al, 2019). Nevertheless, the concept of sports tourism development must be harmonized with the community's involvement that positively impacts both economically and socially and culturally. This study further sees how the community empowerment in developing sports tourism as an inclusive economic driver.

\section{LITERATURE REVIEW}

\section{The Concept of Sport Tourism}

Ottevanger (2007) in Lupikawaty and Wilianto (2013) stated that Sports Tourism is 


\section{Zulkifli Harahap and Titing Kartika: Community Development in Sports Tourism Development as Inclusive Economic Driver in South Sumatera}

an individual and/or group of people who participate actively or passively in the competition or recreational sports. Thus, sport becomes the primary motivation for travelling, although the trip elements can strengthen the overall experience. Furthermore, in the articles, it was found that the primary motive why people want to visit a significant sporting event is the only motive of pleasure, followed by the entertainment factor and the organized destination event.

Agreed about sports tourism, Ritchie and Adair (2004) in Ward and Sanawiri (2018) believed that sport-competition typically associated with tourist behaviour is active (participating in sports), while sports competition usually associated with sport-asplay (witness Sports). Ritchie and Adair (2004) concluded that sports-competition and sport-as-play are a legitimate way of conceptualizing the physical activity that we usually think of as sport. It is like saying that sport as a tourism product.

\section{Inclusive Economic Development Indicators}

a. Economic growth

Ivanov and Ivanova in Lupikawaty and Wilianto (2013) discussed the advantages and leisure travel costs from three different perspectives: economic, social, and environment of the event. They also said that many of the early research was analyzed from the economic perspective only. According to the paper's findings, many positive economic benefits may outweigh the negative environmental or social impacts. Moreover, more residents consider the event as a benefit event overall.

b. Income distribution and poverty reduction BPS (2018) stated that the poor number in South Sumatra per September 2017 amounted to 1086.76 thousand people or 13.10 per cent of the population. The data showed the decline in poverty of South Sumatera in 2017.
Table 1. Number of Poor People in South Sumatra per September 2017

\begin{tabular}{lll}
\hline Urban & 2016 & $\mathbf{1 2 . 7 3 \%}$ \\
\cline { 2 - 3 } & 2017 & $12.36 \%$ \\
\hline \multirow{2}{*}{ Rural } & 2016 & $13.77 \%$ \\
\cline { 2 - 3 } & 2017 & $13.54 \%$ \\
\hline
\end{tabular}

Source: BPS, 2019

c. Expanding access and opportunity

According to Ferrand and McCarthy (2009), sports tourism became a popular activity in the last decade and not separated from public life and the environment (natural environment and the socio-cultural environment). It becomes the main thing to consider the environment in sports tourism. In the neighbourhood, there are sports tourism main activities, namely the practice of sports and event organizers and recreation.

\section{Development and Empowerment}

In the era industry, people do not just use natural resources, but also have the awareness and ability to take care of natural resources. In this context, sports tourism became one of the commodities that can be processed and used as a form of industry. Human behaviour in sports is not just a physical activity or is not just a pastime, but already serves as a valuable tourist economy.

Along with its development, the concept of sport tourism developed in the region Jakabaring Sports City is an integrated concept between smart sport and eco-green. Through this approach, the concept of sports activities was seen as a routine physical movement and became part of the environment's awareness.

Hardinata (2010) in Sholeh (2014) stated that community empowerment puts people as the centre of attention and is perceived and positioned as a subject in the development process.

As quoted by Ife, empowerment should be aimed at three things, namely:

a. Enabling: help people to recognize their potential and capabilities, unwilling to properly formulate the problems that they face, as well as encourage them to have the 


\section{Zulkifli Harahap and Titing Kartika: Community Development in Sports Tourism Development as Inclusive Economic Driver in South Sumatera}

ability to formulate a vital agenda and implement it in order to develop potential and cope with the problems they face.

b. Empowering: strengthens and power possessed by the villager's premises with different inputs, and the opening of the access leads to various opportunities. Strengthening includes human capital, natural capital, financial capital, physical capital, and social capital.

c. Protecting: encourages the establishment of the structural arrangements that protect and prevent the weak from being weakened. Protecting does not mean isolating and covering interaction because it will dwarf the small and weaken the weak. Protecting should be seen as an attempt to prevent the unbalanced competition and the exploitation of the strong over the weak.

In connection with the industry point of views, are supposed to utilize the approach developed by Smith and Cadwick in Mohammed (2016: 76-78), there are three groups in the sports sector as follows:

a. Governmental sports sector

Smith's perspective has become a social fact that sport is a public activity that has great potential and advantages related to economic, social, and political interests. Moreover, a sports event likely to evolve during the development of civilization has reached its peak. Although it is hard to understand the ultimate meaning of civilization, we can interpret the market sports event that is an area of concern for the government in developing the sports event. Governmental sports sectors or sectors of public sports have a limited market area and government policy areas' administrative area. Taking Cadwick's phrase, the government promotes and markets the sports to the public and forms a timeline for national sports events. The birth of national teams representing the country, particularly for the benefit of the
Olympic sports or cross country sports competence, is a simple form of government sports activities.

b. Private sports sector (the commercial sector or corporate sports sector)

These types of the sports sector could be called as professional or profit sport. The organizers of this event and even the athlete itself has the goal of financial gains. The commercial sports market is much broader than the public sector, for example, in developing the sports business such as Inter Milan from Italy, Real Madrid and Barcelona from Spain, or Manchester United from England. They expanded their business to Asian countries, including Indonesia. It illustrates that the sports market wing commercial event reach the whole community to the country.

c. Non-profit sports sector or voluntary sector Non-profit sports intends to provide public servants rather than for material profit. For example, the emergence of community sports clubs intended to raise funds for humanity's benefits, and the other examples are educational sports activities.

\section{Sports Tourism and Inclusive Economy}

Anton and Camarero (2017) stated that "Attracting tourist to a specific destination for normally Relatively short periods with 'sport' as the motivation for reviews their visit," which means attracting tourists to a particular destination for a period of relatively short time with the aim of sports as motivation for their visit. That definition can be seen as a memorable trip outside the usual environment for passive or active involvement in sporting events where sports are the main reason or motivation for the trip. It is confirmed that the number of tourists who will visit a sports tourism destination number is not small, but in a relatively short time, but with varying frequency. This economic turnaround results in many foreign tourists using rupiah or 
exchanging their dollar currency for shopping rupiah in a destination.

Hind (2018), as President of Asia Pacific Institute for Events Management, stated that the various product segments such as Sports Tourism:

a. Luxury sports such as golf and yachting

b. Access to all sports - Paralympic games

c. Water sports - surfing, diving, canoeing, sailing

d. Mountain adventure sports - rock climbing

e. Master event - for professionals who are mature and elite

f. Professional sports - baseball, football, boxing, FI

g. Sports participation by many times - a pleasant walk and marathon

h. Elite sport - events for professional athletes - World Traithlon

$i$. Major sporting events-Soccer World Cup, World Athletics Championships Sports Great Events - Olympic Games and Asian Games.

Some sports can be implemented in several districts/cities in South Sumatra with adequate international standard facilities. One of them is the city of Palembang has Jakabaring Sport City (JSC) is called a sports tourism destination.

Organizing a sports event is not an easy and inexpensive activity, for there must be an effort that could be developed by building cooperation or collaboration with other parties with interest in the business of sports. To facilitate our understanding of aspects of the industry, the view of Kotler and Keller (2016) regarding the existing economic commodities in the form of goods and services:

Table 2. The Economy Commodity in Sports Event

\begin{tabular}{ll}
\hline Economy & \multicolumn{1}{c}{ Information } \\
Commodities \\
in the Sports \\
Business & \\
\hline 1. Objects & In the first type, many items can \\
& be produced. The objects are not \\
\hline
\end{tabular}

\begin{tabular}{|c|c|}
\hline & $\begin{array}{l}\text { only objects related to sports but } \\
\text { also were not linked directly- } \\
\text { examples: sports shoes, sports } \\
\text { team shirts, and more. }\end{array}$ \\
\hline $\begin{array}{l}\text { 2. Sporting } \\
\text { Events } \\
\text { activities }\end{array}$ & $\begin{array}{l}\text { A very lucrative business, which } \\
\text { is to be the organization of the } \\
\text { competition. } \\
\text { competitions are ranging from } \\
\text { youth sports level in the village, } \\
\text { district, provincial (PORDA), } \\
\text { national (PON), Southeast Asia } \\
\text { (SEA GAMES), and world } \\
\text { events (World Cup or the } \\
\text { Olympics). } \\
\text { Brad R. Humphreys and Jane E. } \\
\text { Ruseski (2008) says that sports } \\
\text { play an essential role in society. } \\
\text { Start of the Olympic Games in } \\
\text { Ancient Greece, Colosseum in } \\
\text { Rome, until the Olympic Games } \\
\text { in medieval Europe, to sports } \\
\text { leagues in various foreign } \\
\text { countries. These activities } \\
\text { provide mass entertainment to } \\
\text { the community and a business } \\
\text { and tourism promotion event for } \\
\text { each place of the organizers- } \\
\text { the sports event not just rely on } \\
\text { ticket sales but also the domino } \\
\text { effect of these activities. } \\
\text { Economic sectors such as hotels, } \\
\text { culinary, attributes, tours, and } \\
\text { impromptu workers could } \\
\text { benefit from such activities. }\end{array}$ \\
\hline 3. Persons & $\begin{array}{l}\text { It is most prominent in the sports } \\
\text { event is talking about athletes, } \\
\text { for example, football. Both in } \\
\text { Indonesia and Europe, the } \\
\text { transfer market has become an } \\
\text { annual agenda. Practical lobbies } \\
\text { can be done in such a way to buy, } \\
\text { sell, exchange, or loan players. } \\
\text { These lobbies are prestige and } \\
\text { generate billions of rupiah as an } \\
\text { economic opportunity. }\end{array}$ \\
\hline 4. Service & $\begin{array}{l}\text { In some communities with a } \\
\text { sports culture, it is essential to } \\
\text { confirm sport as a local cultural } \\
\text { identity, for instance, the martial } \\
\text { arts training centre in China, } \\
\text { Korea, and Japan. The sport is as } \\
\text { popular as football in Indonesia. } \\
\text { The culture can not be ignored in } \\
\text { any way to support the } \\
\text { organization of sports events, } \\
\text { provoke growth and } \\
\text { development of services such as } \\
\text { transportation, aviation services, } \\
\text { security services, banking }\end{array}$ \\
\hline
\end{tabular}




\begin{tabular}{ll}
\hline & services, and health services. All \\
& of this indicates that sports \\
& tourism is a powerful magnet to \\
& provoke economic activities. \\
\hline 5. Location & Some areas could be developed \\
& for Indonesia as a tourist \\
& attraction, such as Jakabaring \\
& Sport City (JSC) in Palembang \\
& that having several sports venues \\
& in the region. \\
\hline 6reat football clubs often \\
provide rest to breaks visit or \\
visiting fans in another \\
hemisphere. It was made for the \\
spare time activities of Club \\
members' and strengthened the \\
relationship with the fans' \\
emotions. Thus, fans could feel \\
the sensation of sports activities \\
directly.
\end{tabular}

Source: Researcher, 2019

\section{RESEARCH METHOD}

This study used a qualitative approach. Bungin (2013) said that qualitative research is a series of limited targets and depth of data without limits. We used this approach so that the community empowerment in the development of Sports Tourism can be explored deeply, especially from an inclusive economic perspective.

To strengthen the results, we added observation and documentation study while also conducted interviews with the community to determine the extent of empowerment and its impact on their lives from the development of Sports Tourism in Palembang in South Sumatra. Moreover, the data's technical analysis included several stages, such as initial data collection, data processing, discussion, and conclusions of research results.

\section{RESULTS AND DISCUSSION Sports Tourism in South Sumatra}

a. History of Sports Tourism in South Sumatra

South Sumatra is one of the provinces that has a lot of tourism potential. Based on Data from the South Sumatra Culture and Tourism Office in 2019, South Sumatra ODTW Number: 762 DTW, natural attractions: 383 DTW (50.26\% of total DTW), Cultural tourism: DTW 284 (37.27\% of total DTW), artificial Travel/Special Interest: 95 DTW (12.47\% of total DTW). The average growth of DTW in South Sumatra Province during the period $2009-2018$ by $11.14 \%$. The development of tourism in South Sumatra is supported by various supporting facilities such as hotels, travel agents, restaurants, tourist attractions with diverse attractive tourist attractions. Administratively consists of 17 districts/cities.

Regional autonomy gave authority to the respective district/city, but on the other hand, it raises competition specialized product mix. One of them is Palembang, as regions with rapid growth and developments of sport tourism, culture, and religion have too many places to visit. As time goes by, It has now 
changed to travel with more specific desire or often called special interest tours.

Wardana and Sanawiri (2018) said that one of the special interest that has garnered particular attention is travel related to sports tourism. Sports tourism is one of the recreational experiences that positively impact economic terms in different countries. The contribution of sport to the gross domestic product of industrialized countries is between $1-2 \%$, while tourism contributes between $4-6 \%$. UNWTO (2015 indicated that the fastest development of sports tourism in Indonesia is $6 \%$ per year or about $\$ 600$ billion annually. Also, it is recorded that for $25 \%$ of the total receipts travel and tourism industry.

The tourism industry is regarded as the fastest growing industry. The tourism sector's development is expected to benefit the community because the tourism sector is one economic development sector. Efforts to develop Indonesian tourism is supported by Law No. 10 of 2009 on tourism. The law mentions that tourism in the region will significantly benefit in some ways, such as increase revenue, improve people's lives, expand employment opportunities, increase the awareness of the environment, and preserve nature \& culture.

b. Government policy (priorities) field of Sports tourism

Table 3. Government Policy (priorities) field of Sports tourism

\begin{tabular}{|c|c|c|}
\hline & $\begin{array}{l}\text { Role of } \\
\text { Government }\end{array}$ & Information \\
\hline 1. & Regulator & $\begin{array}{l}\text { The government has } \\
\text { the authority to } \\
\text { develop policies, } \\
\text { regulations, and } \\
\text { decisions regarding } \\
\text { the consequences and } \\
\text { barriers to the } \\
\text { delivery of Sports } \\
\text { Tourism. }\end{array}$ \\
\hline 2. & Dynamist & $\begin{array}{l}\text { Government raises the } \\
\text { dynamics in the } \\
\text { implementation of a } \\
\text { sustainable Sports } \\
\text { event. }\end{array}$ \\
\hline
\end{tabular}

3. Facilitator

Government helps to provide insight to stakeholders and helps to create a plan to achieve those goals together.

c. Sports facilities and supporting infrastructure of sports tourism

Facilities and infrastructure in supporting sports tourism consists of;

1. Transportation and Tourism

2. Travel Agent and Tour Operators in the Tourism Industry

3. Tourism accommodation

4. Tourism Catering Industry

5. Supporting Infrastructure of Tourism

- General Infrastructures)

- Basic Need of Civilized Life

- Tourism Infrastructures

d. Sports Tourism Event had been held in South Sumatra

Palembang community has a new pride, so it has been logical that Jakabaring Sports City (JSC) made a new icon of Palembang are on a massive magnet for local and foreign tourists. The local government is always trying to make Palembang the host venue for major events nationwide and even internationally to attract more tourists. The events that have been organized are:

Table 4. Multi Sports Event/Single Event has been held in South Sumatra

\begin{tabular}{lll}
\multicolumn{1}{c}{$\begin{array}{c}\text { District/ } \\
\text { City }\end{array}$} & $\begin{array}{c}\text { Central } \\
\text { Gov }\end{array}$ & \multicolumn{1}{c}{ Event } \\
\hline Four & Tebing & Musi Triboatton \\
Lawang & Tinggi & \\
\hline South Ulu & Muaradua & Tour de Ranau \\
Komering & & \\
Ogan & & \\
\hline Musi & Sekayu & Musi Triboatton \\
Banyuasin & & \\
\hline Lubuk & - & Lubuk Linggau \\
Linggau & & MTB National \\
& & Championships \& \\
& & $\begin{array}{l}\text { International Race, } \\
\text { 150 participants } \\
\end{array}$ \\
& & from 7 countries. \\
\hline
\end{tabular}




\begin{tabular}{ll}
\hline Palembang - & National Sports \\
& Week (PON) XVI, \\
& participants 33 \\
provinces (Sep, & 2004). AFC Asian \\
& Cup co-hosts \\
& Malaysia, Thailand \\
& and Vietnam, (Jul, \\
& 2007). SEA \\
& GAMES, \\
& participants 11 \\
& ASEAN countries, \\
& (Nov, 2011). The \\
& Islamic Solidarity \\
& Games, participants \\
& 44 countries of the \\
& Islamic world (July, \\
& 2013). ASIAN \\
& GAMES Jakarta- \\
& Palembang \\
& participants 45 \\
Asian countries \\
(Aug, 2018). \\
\hline & Nature Heritage \\
& Trail, Pagar \\
\hline
\end{tabular}

Community Empowerment in the Development of Sport Tourism as an Inclusive Economy Driver in South Sumatera

a. Elaboration form of empowerment in the development of sports tourism in the concrete example of Sumatera and other areas

Community empowerment is taking sides, preparing, and protecting people. Empowered people mean people who can fulfil their own needs, can produce and enjoy the products they made. In the economic context, enjoy means consumption, while producing means production. Empowered people mean the people who can survive independently, follow market mechanisms, and exchange their products as income sources. Saving some money for the future is the most basic stage of empowerment. Those who can save are identified as independent human beings that fulfilled their current life needs and future needs or broader investment.
Table 5. Community Empowerment in Development of Sports tourism concrete examples of the period 2016-2019

\begin{tabular}{ll}
$\begin{array}{l}\text { Implementation } \\
\text { of Sports Event } \\
\text { Tourism }\end{array}$ & \multicolumn{1}{c}{ Information } \\
\hline $\begin{array}{l}\text { London- } \\
\text { England }\end{array}$ & $\begin{array}{l}\text { The event presented more } \\
\text { than 40K runners who run }\end{array}$ \\
-London & the historical sidewalks. \\
Marathon & $\begin{array}{l}\text { Many of them wear unique } \\
\text { clothes made by local } \\
\text { artisans (source: }\end{array}$ \\
& www.visitlondon.com) \\
\hline
\end{tabular}

Banyuwangi,

East Java-

Indonesia: -held in March in the village

-Chocolate of Cocoa- Glenmore

Cycling managed by local farmers.

Challenge -Passing local durian trees'

(CHC) farmers around the

-Durian Happy subdistrict Songgon.

Cycling -The cycling community

accommodate both nationa

-Cycling and international female

Woman participants by wearing

Competition local clothing of

(WCC) Banyuwangi.

-Exchanging the culture of

-International the community

Tour de Ijen consolidation up to the

(ITdBI) lowest level.

(Source: the magazine of

Garuda colors Indonesia-

www.garuda-

indonesia.com)

\section{Padang, West}

Sumatra-

Indonesia $\quad$-A sports event with the

-Tour de world's fifth-highest

Singkarak(TDS) number of visitors,

provided 7 etapes and

$818.5 \mathrm{~km}$ distances.

Involved 14 of the 19

districts/cities in West

Sumatra.

\section{South OKU- \\ Palembang-}

South

Sumatera - A pride sports events of

-Tour de Ranau South OKU, offering

natural scenery is the

-Musi Triboatton largest lake after Lake

Toba in Sumatra. 
- A Water Sports event that is consistently carried out to raise the culture of the river banks of Musi, with a distance of $500 \mathrm{KM}$.

Optimizing the development of local initiatives to increase income, selfsufficiency, and well-being will be easily achieved if developed regional cooperation between local societies. This cooperation is important because the obstacles and potential of human resources, natural resources, and region characteristics are not in the same conditions. Cooperation between local agencies will foster the development of a synergistic approach. Second, as a forum for coordination of regional development planning to run without harming public access and other areas. In Act No. 32 of 2004 on Regional Government, establishing the regional authorities is that each autonomous region has the authority to regulate and manage their domestic affairs within the framework of the Unitary State of the Republic of Indonesia. With autonomy, regional governments will be able to implement community development and empowerment programs to the region's real conditions. Besides, with autonomy, accelerating regional development can be implemented because autonomy provides better financial opportunities, which will create prosperity for the community if used to the maximum.

Each region has a different geographical situation. The conditions and situations in the region need to be controlled by each leader to make it easier to make decisions and actions to develop economic potential. We realize that each region in Indonesia has different economic potential. In this context, Palembang has the nickname sports tourism because it has exclusive sports venues that are of international standard. So that every national and international sporting events are often held in Palembang, this can provide excellent opportunities for business people in the city of Palembang. However, the extent to which communities and local governments focus on business opportunities and community economic empowerment. The impact of tourism on the economic conditions of the local community can be categorized into the top eight groups of Pitana (2005) in the Medan Akpar journal, namely: The impact on foreign exchange earnings;

1. The impact on public revenue;

2. The impact on employment;

3. The impact on prices;

4. The impact on the distribution of benefits/gains;

5. The impact on ownership and control;

6. The impact on development in general;

7. The impact on government revenue.

b. The impact of Sports tourism towards the inclusive economy on three main pillars:

\section{Economic growth,}

Collaboration among Sports businesses encourages a shift in values and human perception of the Sports. The sports event is no longer a physical activity of human activity and entertainment but becomes part of the economic commodity. One of the most important aspects of developing the creative economy in Indonesia is creating creative entrepreneurs that will play an important role in developing the creative economy. Currently, Indonesia has not entered into the group of industrialized countries because there are many aspects of the problem in developing a national industrial sector. One of them is the lack of business people or entrepreneurs in the economic sector, especially the creative economy. Indonesia has only 440 thousand entrepreneurs or around $0.2 \%$ of the total population.

Creating entrepreneurs in the creative economy sector are not easy because of many influencer aspects. From several problems faced in the development of entrepreneurship in Indonesia, here are some important issues that have occurred to result in the 
development of an entrepreneurial spirit in Indonesian society: cultural factors. Related to Indonesia's historical background that was experiencing colonialism, the Indonesian people are more worker-minded and 'not entrepreneurial. This complicated national problem leads to a weak educational system that fosters an entrepreneurial attitude in Indonesian society.

- Government policies to encourage the creation of creative entrepreneurship are still relatively small. The direction of national policy prioritizes the interests of large-scale industry.

- The potential of natural resources (SDA) in Indonesia is still very large as an input of the craft industry, cultural wealth, mineral wealth and local wealth that has not been tilled.

- Indonesia is in the stage of economic development leading to developed industrial countries in the Asian region if government policies are in a good corridor and macroeconomic stability can be well maintained then Indonesia has the potential to be the main driver of the regional economy.

- The mobilization and development of science, technology and information in Indonesia are getting better, even though the utilization aspect of the industrial sector is not yet large.

\section{Income distribution and poverty reduction}

The sports event is as the business media. The sports industry is not solely related to the marketing of products from a variety of Sports elements.

\section{Expanding access and opportunity}

The phenomenon of sport tourism, the symptoms of commercialization, and industrialization of a sustainable sports event. This is not only a proof of the interaction between sports and the life of modern society, and also because there is a change in people's understanding of the status of sport as a strategic position and the growth and development of a sports business that benefits society, the nation and the state.

\section{CONCLUSION}

The governments set several cities in South Sumatra as Sports Tourism Destinations. They support the regulation by providing international standard sports facilities and areas such as Jakabaring Sport City. Unfortunately, the support is not given in maximum synergy and marketing strategies due to the absence of Brand Awareness from the community and local government regarding Sport Tourism in South Sumatra. This is what underlies researchers to be able to analyze and provide conclusions and suggestions regarding the above topics, namely: designation as a Sport Tourism Destination must be supported by local government and local communities; local governments must play an active role in maximizing the use and visit of sports tourism areas in order to become (State Budget) APBD; and digital media which is currently a hot topic in Indonesia can be used as a reference and background for marketing digital or technology-based tourism products.

\section{REFERENCES}

Antón, C., Camarero, C., \& Laguna-García, M. (2017). Towards a new approach of destination loyalty drivers: Satisfaction, visit intensity and tourist motivations. Current Issues in Tourism, 20(3), 238260.

Bungin, B. 2013. Penelitian Kualitatif: Komunikasi, Ekonomi, Kebijakan Publik dan Ilmu Sosial Lainnya. Jakarta: Kencana Prenada Media Group Jamal, T., \& Stronza, A. (2009). Collaboration theory and tourism practice in protected areas: Stakeholders, structuring and 
sustainability. Journal of Sustainable tourism, 17(2), 169-189.

Kotler, P., Keller, K. L., Armstrong, G., Armstrong, G., \& Keller, K. (2016). Marketing management. 15th Global Edition.

Lupikawaty, M., \& Wilianto, H. (2013). Potensi Sport Tourism di Kota Palembang: Perspektif Ekonomi. Jurnal Ekonomi dan Informasi Akuntansi, $3(2)$.

Muhammad, Mamet, \& dkk. 2016. Sport Marketing; Memasarkan dan Mengembangkan Industri Olahraga. Yogyakarta: Laksitas

Pitana, I. G., \& Gayatri, P. G. (2005). Sosiologi Pariwisata: Kajian sosiologis terhadap struktur, sistem, dan dampakdampak pariwisata. Andi.

Revindo, M. D., Widyasanti, A. A., Siregar, C. H., Anindita, D., Hastuti, N. W., \& Hambali, S. (2019). Long-Term Effect of Mega Sports Event on Host Country's Tourism: Evidence From the Jakarta-Palembang 2018 Asian Games. Institute for Economic and Social Research.

Sholeh, Chabib. 2014. Dialektika Pembangunan dengan Pemberdayaan. Bandung: Fokusmedia

Wardana, A. P., \& Sanawiri, B. (2018). Potensi sport tourism sebagai daya tarik wisata di Malang Raya (Studi kasus pada klub sepakbola Arema FC). Jurnal Administrasi Bisnis, 55(1), 180-187.

Web:

administrasibisnis.studentjournal.ub.ac.id

(Diakses: 3-4-2019.pkl.20.30 WIB) 